\title{
OS CASTRATI: A CASTRAÇÃO COMO TECNOLOGIA DE INTERVENÇÃO CORPORAL.
}

\author{
THE CASTRATI: CASTRATION AS THE TECHNOLOGY OF SPEECH BODY
}

\author{
Isis Moura Tavares ${ }^{1}$ \\ Marília Gomes de Carvalho ${ }^{2}$
}

\begin{abstract}
Resumo
A intenção desse texto é analisar as relações entre corpo, gênero, música e tecnologia, tendo como referência principal dessa análise os castrati, homens castrados antes da puberdade para manter sua voz aguda mesmo na idade adulta. Durante o período barroco europeu, o uso da castração como tecnologia de intervenção corporal gerou um dos maiores e, curiosamente, menos conhecidos fenômenos da música vocal ocidental. A castração dessas crianças criava nos grupos sociais aos quais pertenciam uma relação entre corpo, arte e tecnologia sui generis, pois a construção cultural do corpo desses meninos se dava a partir de um corpo biologicamente masculino mutilado, na maioria das vezes sem consentimento. A intervenção corporal forçada criou um grupo social único, que cumpriu importante papel na história da música vocal ocidental, valorizando e marginalizando esse corpo à margem, tornado-o objeto de desejo e horror no período barroco da história da música. Palavras-chave: Corpo; gênero; música; tecnologia; voz
\end{abstract}

\begin{abstract}
c
The intention of this paper is to analyze the relationship between body, gender, music and technology, with the main reference of this analysis the castrati, men castrated before puberty to keep their voices acute even in adulthood. During the period baroque European castrating the use of technology such as the intervention has created a body of the largest and, curiously, less known phenomena of Western vocal music. The castration of these children in creating social groups which belonged to a relationship between body, art and technology sui generis, because the cultural construction of the body where these boys came from a mutilated body biologically male, in most cases without consent. The intervention force has created a body unique social group, which met important role in the history of Western vocal music, valuing and marginalizing the body to shore, making it the object of desire and horror in the period Baroque of history of music.
\end{abstract}

KeyWords: Body; Gender; Music; Technology; Voice.

\section{MÚSICA E GÊNERO}

Existe uma forma de ver o mundo e interagir com ele que é própria da arte, da estética. Prova disso é a existência da arte cumprindo as mais diversas finalidades, desde os tempos mais remotos e nas manifestações de todos os povos, em todas as épocas. A música, por exemplo, manifesta-se na religião, no divertimento, no ensinamento, na

1 Mestranda em Tecnologia pelo Programa de Pós-Graduação em Tecnologia - PPGTE da Universidade Tecnológica Federal do Paraná - UTFPR. Pesquisadora do Grupo de Estudos e Pesquisas sobre Relações de Gênero e Tecnologia - GeTec. E-mail: isismt@terra.com.br.

2 Doutora em Antropologia Social pela Universidade de São Paulo - USP, professora do PPGTE/UTFPR, coordenadora e pesquisadora do GeTec. E-mail: mariliagdecarvalho@gmail.com. 
revolta, na tristeza, nas declarações de amor e no puro prazer estético dos povos de todos os tempos.

Toda música tem uma intenção, é executada por determinadas pessoas, em situações diversas e cumpre um papel específico na cultura dos povos. No caso, referimonos à cultura não como educação acadêmica, erudita ou escolar e sim como "maneira de viver total de um grupo, sociedade, país ou pessoa [...] um código através do qual as pessoas de um dado grupo pensam, classificam, estudam e modificam o mundo e a si mesmas." (MATTA, 1986, p. 123).

Dentro desses contextos percebe-se, muitas vezes de forma explícita, relações de gênero. A socióloga Heleieth I. B. Saffioti esclarece que, "partindo-se do pressuposto que as sociedades constroem imagens sobre o masculino e o feminino, toda sociedade manifesta, em alguma instância, relações de gênero.'(SAFFIOTI, 2004, p. 16)

A música passou por inumeráveis transformações durante a existência humana, adaptando-se ou rompendo padrões. E o papel dos gêneros dentro dessa linguagem artística também se modifica constantemente, acompanhando as necessidades criadas pelas sociedades.

Falar sobre gênero remete a inúmeras discussões, análises, construções e reconstruções. São muitos os autores e autoras que estudam os gêneros, os sexos e sua relação. Não é a intenção desse trabalho analisar ou refletir sobre todas as questões decorrentes da categoria gênero, mas apontar alguns pontos de reflexão que facilitem, ou até, tornem mais complexo, o entendimento do papel social dos castrati na Itália Barroca, objeto dessa pesquisa, que merece aprofundamento em trabalhos posteriores.

Muitos dos textos e comentários que se ouve sobre gênero no mundo acadêmico parte do princípio de que o sexo é determinado biologicamente e o gênero culturalmente:

Para um biólogo, "macho" significa produzir gametas pequenos e "fêmea", produzir gametas grandes. E ponto final! Por definição, o menor dos dois gametas é chamado espermatozóide, e o maior, óvulo. [...] O ponto-chave aqui é que "macho" e "fêmea" são categorias biológicas, enquanto "homem" e "mulher" são categorias sociais. Homem e mulher diferem em muitos graus sociais, além da dimensão biológica do tamanho do gameta. (ROUGHGARDEN, 2000, p. 25).

De acordo com a mesma autora, "a maioria das espécies que se reproduz sexuadamente, possui machos e fêmeas, com gametas pequenos e grandes respectivamente, definindo os dois sexos. Porém, para ela, os gêneros, diferentemente do tamanho dos gametas, não se limitam a dois." (ROUGHGARDEN, 2000, p. 28)

Portanto, existem muitos masculinos e femininos que são construídos socialmente, assumindo-se como corpo masculinos e femininos, tomando atitudes de "homens " ou "mulheres" a partir de elementos culturais que ultrapassam e se mesclam a elementos biológicos. Podemos, diante dessas reflexões, arriscar dizer que existem muitos gêneros além do masculino e feminino:

Nos tempos modernos o termo gênero foi usado pelas feministas americanas para dar uma conotação relacional e não determinista sobre "sexo" ou "diferenças sexuais". A partir dessa visão, homens e mulheres não poderiam ser designados como homens e mulheres sem que fossem analisados e analisadas em relação e interação. Além disso, existia uma grande preocupação das historiadoras em pesquisar a história e os acontecimentos tirando as mulheres da invisibilidade e incluindo-as nos acontecimentos sociais. (SCOTT,1995, p. 79)

A partir daí, o termo gênero, enquanto categoria de análise, sofreu e sofre transformações constantes, cabíveis a um termo que se refere a seres humanos e suas 
relações, principalmente ao pensarmos que essas relações são permeadas por desigualdades sociais, abusos de poder, marginalizações, enfim, práticas culturais que acabam por determinar papéis e, conseqüentemente, determinar corpos e suas relações.

Vários autores e autoras, como Scott e Pierucci, por exemplo, afirmam que gênero é uma categoria social ou cultural que tem como base um corpo sexuado. Portanto, voltamos à nossa discussão inicial que é apoiada em um corpo biológico, macho ou fêmea. A partir desse corpo muitas relações e determinações vão sendo feitas em todas as esferas da sociedade e na subjetividade de cada indivíduo. Nesse ponto nos voltamos para a situação dos castrati do período Barroco: uma criança com seu corpo biológico, seu sexo, mutilado, que nessas condições estabelece relações sociais como ser assexuado, como mulher, como homem, como herói, como anjo.

Laquer apresenta-nos uma discussão profunda e complexa sobre o sexo, resgatando sua história, intrínseca à do ser humano. Este autor coloca que durante milhares de anos os estudiosos acreditavam que as mulheres tinham a mesma genitália dos homens, só que dentro do corpo. Estes estudiosos, dos primeiros séculos depois de Cristo, analisavam os órgãos das mulheres em paralelo com o dos homens e a linguagem usada durante séculos para mostrar estas relações entre os corpos dos machos e fêmeas mostra claramente como o corpo do macho era a referência.

Durante dois milênios o ovário, um órgão que no início do século XIX se tornou uma comparação da mulher, não tinha nem ao menos um nome específico. Galeno refere-se a ele com a mesma palavra que usava para os testículos masculinos, orcheis, deixando que o contexto esclarecesse o sexo ao qual se referia. Herófilo denominara os ovários de didymoi (gêmeos), outra palavra padrão grega para testículos, e era tão preso ao modelo mulher-como-homem que achava que as trompas de Falópio (Fallopius) - os canais ejaculatórios que saem de cada um dos testículos - ligavam-se no pescoço da bexiga, como ocorre com os canais ejaculatórios do homem. (LAQUER, 2001, p. 16)

Ainda de acordo com Laquer, foi no século XVIII que a natureza sexual humana mudou, mudando também a compreensão do papel social dos homens e mulheres: "Não só os sexos são diferentes, como são diferentes em todo aspecto concebível do corpo e da alma, em todo aspecto físico e moral.” (ROSSEAU apud LAQUER , 2001, p. 17)

Os pensadores desse século e do seguinte baseavam as diferenças entre homens e mulheres nas questões biológicas, sedimentadas durante anos de evolução genética. Para eles existiam dois sexos opostos e estáveis e a vida social destes dois sexos, inclusive a dominação de um sobre o outro, estavam baseadas nessa biologia: "Os organismos microscópicos que rolaram no limo primordial determinaram as irredutíveis distinções entre os sexos e o lugar de cada um na sociedade.” (LAQUER, 2001, p. 18)

É interessante perceber como o termo gênero assume distintas definições dependendo do contexto no qual está inserido. Laquer comenta, por exemplo, que em textos pré-iluministas, o sexo é sinônimo de corpo e considerado o epifenômeno, enquanto que o gênero, considerado atualmente como uma categoria cultural, era primário e real.

Aprofundando essa discussão, Laquer ainda ressalta que a relação entre sexo e gênero sempre foi controversa e tensa. "Enquanto algumas linhas de pensamento embasam suas teorias a partir do sexo biológico, natural, outras excluem o natural "esvaziando o sexo" de seu conteúdo.” (LAQUER, 2001, p. 23)

Essa relação entre sexo e gênero também é discutida por Butler, que contesta a análise e designação binária dos sexos, ressaltando as questões naturais e culturais que envolvem a construção da categoria gênero: 
Em algumas explicações, a idéia de que o gênero é construído sugere um certo determinismo de significados do gênero, inscritos em corpos anatomicamente diferenciados, sendo esses corpos compreendidos como recipientes passivos de uma lei cultural inexorável. Quando a "cultura" relevante que "constrói" o gênero é compreendida nos termos dessa lei ou conjunto de leis, tem-se a impressão de que o gênero é tão determinado e tão fixo quanto na formulação de que a biologia é o destino. Nesse caso, não a biologia, mas a cultura se torna o destino. (BUTLER, 2003, p. 26)

Diante de tantas análises e questionamentos, tantas possibilidades de pensamento e tantas definições de gênero, muitas questões merecem ser aprofundadas posteriormente, porém, nessa pesquisa, iremos assumir como tendência as afirmações de Scott: "o gênero não é uma categoria mediadora entre a diferença biológica fixa de um lado e as relações sociais historicamente contingentes do outro. O gênero inclui tanto a biologia quanto a sociedade: um elemento constitutivo das relações sociais baseadas em diferenças aceitas entre os sexos...uma forma básica de expressar relações de poder." (SCOTT apud LAQUER, p. 24)

Assim sendo, os castrati possuem um corpo biológico que não se encaixa em nenhum dos sexos estabelecidos (macho ou fêmea), e um papel social que não se encaixa em nenhum dos gêneros, ou melhor, um papel social que delimita um gênero próprio.

Mesmo na sociedade da época, na qual a prática da castração era tolerada, percebemos que os castrati eram vistos como "seres à parte", enaltecidos como artistas mas marginalizados como pessoas em muitos aspectos.

O novo gênero (a ópera) institui a soberania do cantor: é ele, o indivíduo, que está no centro, em vez do coro. Parece-se com o monarca absoluto, esse outro personagem central do Barroco, podendo dizer: La musique c'est moi. Em seu torno gira a corte toda de arquitetos e maquinistas de que se precisa para encenar o espetáculo. (CARPEAUX, 2004, p. 60)

Por outro lado, não tinham, por exemplo, autorização para casar "a extração dos testículos os impedia de procriar mas não, na maioria dos casos, de manter relações sexuais. [...] Isso fez com que alguns dos castrati chegassem até a tentar se casar, embora isso não fosse sancionado pela Igreja." (COELHO, 2000, p. 194)

Essa dicotomia entre "o bem" e "o mal", entre "macho" e "o que não procria", entre "o famoso" e "o que deve ser escondido", reflete-se na vida dos castrati desde a sua formação, na infância e todas essas relações de gênero sempre estiveram presentes na música da maioria dos povos, em diversos tempos e na divisão sexual do trabalho dentro dessa linguagem artística..

\section{TECNOLOGIA VOCAL}

A voz é o mais antigo, sofisticado e universal instrumento musical. "A música é a nossa mais antiga forma de expressão, mais antiga do que a linguagem ou a arte; começa com a voz e com a nossa necessidade preponderante de nos dar aos outros. De fato, a música é o homem, muito mais do que as palavras [...]" (DAVIS; MENUHIN, 1990, p. 1)

O uso da voz na música é tão antigo quanto as primeiras civilizações. Segundo o Novo Testamento, por exemplo, Moisés e os Israelitas cantavam a Deus quando foram libertados dos egípcios. Os gregos e romanos antigos tinham a música e o canto como parte da formação do indivíduo. "As tradições judaicas de louvor a David através do canto foram incorporadas ao culto-cristão, e é esse momento histórico que a maioria dos 
autores pontua como o início da música vocal erudita ocidental.” (STANLEY, 1995, p. 18)

Foi na Idade Média que os primeiros monges escreveram a música vocal à capella que executavam nas cerimônias religiosas, o cantochão.

O desenvolvimento da música religiosa nos séculos seguintes se deu paralelamente ao desenvolvimento arquitetônico. À medida que as catedrais, abadias e mosteiros ficavam mais suntuosos e grandiosos, a música religiosa foi se tornando mais elaborada, sendo que no período do renascimento musical, aproximadamente século XV e XVI, os coros eram grandes e chegavam a ter 30 ou 40 vozes, isto é, 30 ou 40 melodias diferentes sendo executadas simultaneamente.

Durante todo esse período e o anterior, era proibida a entrada de mulheres nos coros, nos quais as vozes mais agudas eram executadas por crianças ou por falsetistas, cantores que usam uma técnica vocal especial para conseguir cantar melodias mais agudas.

Foi no final do século XVI, nos madrigais, forma musical profana vocal, que a voz aguda de mulheres passou a ser aceita e apreciada pela sociedade européia, surgindo mesmo alguns coros femininos na Itália. Porém, as mulheres ainda não podiam, de forma alguma, executar a música religiosa. Esse novo gosto pela voz de registro agudo criou alguns problemas para a igreja, que além de usar os falsetistas, passou a acolher os castrato,

talvez o fenômeno mais extraordinário da história da música, um cantor masculino castrado antes da puberdade a fim de manter a sua voz aguda. O primeiro registro de um castrato na lista de pagamentos do coro da Capela Sistina, em Roma, data de 1599 e, apesar das graves questões morais que esta operação levantou, esses cantores tornaram-se um elemento crucial dos coros católicos na Europa durante os dois séculos seguintes. O último cantor eunuco retirou-se da Capela Sisitina em 1913.

Os castrati não se limitavam aos meios eclesiásticos, tornando-se um dos pilares do gênero secular mais influente e de maior crescimento do século XVII: a ópera. (STANLEY, 1995, p. 19)

A ópera surgiu na Itália no fim do século XVI (renascimento) em Florença e predominou entre os séculos XVII e XIX na Europa. É um drama musical no qual o texto dramático (ópera séria) ou cômico (ópera bufa), chamado libreto, é cantado total ou parcialmente por solistas ou coros acompanhados ou não de uma orquestra.

Nascido na mesma época da ópera, o Oratório é outra importante forma de música vocal barroca. O oratório é um tipo de ópera com histórias baseadas na Bíblia. As Cantatas, outra forma vocal importante do período, são oratórios em miniaturas e eram apresentados nas missas.

Os castrati estavam presentes e eram as "estrelas" de todas essas formas musicais durante o século XVII. Foi, justamente a partir do século XVII e XVIII, com o aumento de popularidade da ópera, que se institui o “culto ao cantor". Em 1880, uma musicóloga londrina, que escrevia sob o pseudônimo de Vernon Lee, escreveu:

Na vida musical do século XVII, o cantor era uma personagem muito mais importante do que é hoje. Não era apenas uma das engrenagens do mecanismo, mas sua alavanca principal. Num país tão natural e espontaneamente musical como a Itália, o desejo de cantar precedia tudo o que pudesse ser cantado: os intérpretes não existiam porque o público desejasse ouvir esta ou aquela composição; a música é que era composta porque havia pessoas que desejavam cantar. Os virtuoses, portanto, não estudavam para executar um tipo particular de música; a esta é que cabia adequar-se aos recursos de que eles dispunham. (COELHO, p. 187) 
É nesse contexto de supremacia do cantor que os castrati dominam o cenário musical, com uma tecnologia vocal própria e única.

Chama-se de técnica vocal "[...] o modo de utilização do conjunto de órgãos que contribuem para a fonação, estabilizado por um sistema neurológico (cérebro), sensitivo (sensorial), motor (tônus muscular) apropriado, que permite ao cantor, orador, professor, etc, as performances de: altura, intensidade, timbre, afinação e...não fadiga." (HUSSON, 1960, p. 15)

Se fôssemos analisar essa definição do ponto de vista estritamente funcional, poderíamos chamar esse capítulo de técnica vocal e não tecnologia, como o fizemos.

No entanto, ele não seria suficiente para, ao menos, apontar a enorme diversidade de "técnicas vocais" que existiram e que existem atualmente. "Não justificaria porque, para os povos orientais, por exemplo, o som vocal é basicamente formado dentro da cabeça e a ressonância encefálica que se reflete na nuca e na face é tão importante e bela, enquanto que para os povos ibéricos o som é mais gutural e laríngeo. Não explicaria como na Mongólia existem cantores capazes de produzir dois sons ao mesmo tempo enquanto a maioria das vozes dos povos negros é escura, aveludada e com grande extensão." (SILVA, 1997, p. 5)

Isso por que a técnica alia-se a um contexto histórico e sóciocultural, a um padrão de beleza, a interessas políticos, a um corpo com características próprias e torna-se assim, tecnologia.

Considerando-se que "a tecnologia perpassa todas as formações sociais porque na produção das condições materiais de vida, necessárias a qualquer sociedade, é imprescindível a criação, apropriação e manipulação de técnicas que carregam em si elementos culturais, políticos, religiosos e econômicos, constituintes da concretude da existência social [...]" (CARVALHO; FEITOSA; ARAÚJO. S/d) vemos que a técnica vocal, enquanto expressão cultural e social das diversas sociedades, é permeada e criada através da tecnologia.

Como ponto de partida, consideramos nesse trabalho que a tecnologia é, partindo de reflexões de Bastos (1998), uma prática social e cultural, que não se esgota na técnica e sim na relação desta com os indivíduos e sociedades. A música vocal é expressão cultural e reflete formas de produzir, compreender, adaptar e expressar, através de sons, a realidade humana. Portanto, existe uma tecnologia vocal, que assim como a arte só tem sentido se analisada dentro de um contexto, "[...] a estreita relação das novas manifestações artísticas com as transformações sociais torna evidente algo que é válido para a arte de todas as épocas: a necessidade de analisá-la junto com seu contexto histórico." (CANCLINI, 1984, p. 3).

De forma resumida podemos dizer que, até, aproximadamente, os 12 anos, as crianças possuem a chamada "voz branca", raramente distingue-se um menino ou uma menina de 3 ou 5 anos pela sua voz. Depois disso, na adolescência, em virtude das alterações hormonais, as mulheres podem ficar com a voz mais grave, e os meninos passam pela "muda", uma transformação fisiológica através da qual sua voz vai, aos poucos, ficando mais grave e profunda. "Uma vez castrado, o menino não passava mais pela muda, ou seja, sua voz não baixava de uma oitava, como em todos os outros rapazes. Permanecia 'alta', para usar um termo muito geral, a meio caminho entre a da criança e a da mulher [...]” (BARBIER, 1993, p. 13)

Naturalmente, as pessoas possuem vozes mais graves ou agudas que são divididas em femininas e masculinas. Com estudo e exercícios vocais as vozes vão se 
tornando mais potentes e alcançando uma maior tessitura (grupo de notas).

Os quatro tipos principais de vozes de ópera, e de outras formas vocais também, são o soprano e o contralto (as vozes femininas mais aguda e mais grave) e o tenor e o baixo (as vozes masculinas, aguda e grave).

Os tenores e os sopranos têm normalmente os papéis principais, enquanto os contraltos e os baixos ficam com papéis auxiliares; os baixos representam muitas vezes os vilões. As outras vozes que pode ouvir são o meio-soprano, que fica entre os registros do soprano e do contralto, e o barítono, que está entre o tenor e o baixo. Existe também o baixo-barítono, um pouco mais grave e profundo no som do que o barítono. A voz masculina adulta actualmente mais aguda é a do contratenor. (WAUGH, 2000, p. 23)

A voz do contratenor é a que mais se aproxima da voz dos castrati do período barroco. Existem algumas divergências dentro das escolas de técnica vocal no que se refere à técnica usada pelos contratenores. Inicialmente cabe ressaltar que um contratenor não é um homem que canta como mulher, pois a sua voz é diferente das sopranos. O que acontece é que muitos tenores usam uma tecnologia de canto no registro superior da voz, ou seja, o falsete ou a voz de cabeça, que se originou no século XVI nas catedrais da Espanha. Mas, com o surgimento dos "castrati", os contratenores perderam sua vez, pois os castrati trouxeram inúmeras mudanças na tecnologia vocal barroca.

Até o século XVII, é provável que os aspectos técnicos do canto estivessem subaproveitados e se baseassem apenas na produção do som a partir da garganta e cabeça. A partir de cerca de 1600, com o advento da ópera, verificara-se que o processo de desenvolvimento da técnica de canto explorara uma maior potência, projeção e vigor da voz, os diferentes timbres e uma maior extensão. [...] A medida que os cantores conseguiam desenvolver estas potencialidades, os compositores, inevitavelmente, escreviam músicas para explorar essas capacidades. (STANLEY, 1995, p. 20)

Nessa questão vemos a intrínseca relação entre tecnologia vocal, sociedade e música. Ao mesmo tempo em que as transformações musicais pediam uma nova tecnologia vocal, essa impulsionava os compositores a modificarem seu estilo de composição, o que gerava novas necessidades sociais e musicais, como o aparecimento dos castrati. "Os castrati tinham força e agilidade vocal, suas vozes podiam facilmente encher até os maiores teatros de ópera; assim, os castrati rapidamente tornaram-se queridos do público e a espinha dorsal da ópera séria do período barroco." (DIGAETANI, 1988, p. 29)

A nível de tecnologia vocal, a ópera barroca rendeu um grande legado: o bel canto. O bel canto é um "elegante estilo vocal italiano dos sécs. XVII a XIX, caracterizado pela beleza de timbre, emissão floreada, fraseado bem feito e técnica fácil e fluente.” (DICIONÁRIO GROVE, p. 90)

Dentro da complexa tecnologia vocal que explica o bel canto, podemos levantar dois procedimentos mais comuns, mesmo que sobre ela não se tenha uma documentação muito vasta, pois se baseava na improvisação. Um deles é a coloratura, através do qual se embeleza e enfeita uma linha melódica. O outro é a cadência, que propõe a ornamentação dos finais de frase. Esses procedimentos eram inseridos nas árias para oferecer ao cantor ou cantora a oportunidade demonstrar todo seu repertório de "truques vocais", e eram amplamente utilizados pelos castrati.

Muitas vezes essas improvisações eram exageradas, o que levou muitos críticos da época a ironizar o uso das cadências:

Cada ária tem pelo menos três cadências, que são outros tantos finais. Em geral, hoje, os cantores preocupam-se em terminar a cadência da primeira parte impingindo-nos a seu bel-prazer um monte de ornamentos e divisões, enquanto a orquestra espera; na segunda, 
aumentam a dose, enquanto a orquestra se aborrece; mas na última, a sua garganta trabalha como se fosse um estandarte durante uma tempestade, enquanto a orquestra boceja. (TOSI apud COELHO, 2000, p. 190)

Guardando as devidas proporções e os exageros dos castrati da época, a técnica do bel canto exige preparo e cuidado com a voz. Só a realiza quem tem um corpo preparado para tal, como é o caso dos castrati, que desde a infância tinham como prioridade sua educação respiratória e de emissão vocal. O corpo que já fora mutilado é moldado, sofre intervenções constantes, para que a voz que emita siga os padrões de beleza instituídos na época: a voz aguda perfeita e potente:

As pessoas têm tendência de ficar mais entusiasmadas com sopranos e tenores. Por quê? Na realidade elas produzem os sons menos naturais, eles são, o número do trapézio. Apesar de os meios-sopranos, barítonos e baixos produzirem sons mais próximos da voz normal da fala, sopranos e tenores produzem sons que são mais excitantes, por que eles não são comuns. Tenores e sopranos geralmente ficam com os melhores papéis na ópera. (DIGAETANI, 1988, p. 138)

Esse timbre anti-natural e mágico tem relação direta com os temas e poéticas do período barroco, que ressaltam os contrastes, o bizarro, a inconstância, a atração pelo sobrenatural e pela intensidade das expressões. Nada melhor que aliar a "mágica" do palco à magia real da castração, que transformava homens em deuses, mulheres, heróis, heroínas e anjos.

\section{CASTRAÇÃO}

Castração é um ato de mutilação sexual em que se incapacita o paciente de reproduzir-se sexualmente. Pode consistir na extirpação de gônadas ou pênis em machos, ou do clítoris, útero ou ovário nas fêmeas. É aplicado em casos de doenças (ou o risco de desenvolvê-las) como câncer, ou, no caso de animais domésticos, para evitar sua proliferação e amansar seu comportamento.

Homens castrados são chamados eunucos, e por não poder se reproduzir, foram por muito tempo escolhidos como guardiões de haréns reais. $<$ http://pt.wikipedia.org/wiki/Castração.

Falar em castração nos remete a hábitos antigos. Alguns povos vitoriosos, citados na Bíblia, castravam seus inimigos para evitar a procriação. Além disso, como os animais castrados se apresentavam com temperamento mais dócil, era costume castrar escravos para evitar rebeliões e revoltas, mais um exemplo de intervenção corporal radical que produz alterações tanto nos padrões corporais como mas atitudes sociais.

Esse costume era praticado pelas civilizações greco-romanas, na África, na Ásia, na Índia e finalmente na Europa:

A beleza lânguida, sinuosa e equilibrada da música mourisca, que deixou sua marca na Espanha toda, soava não apenas nos jardins em flor, mas também dentro, no harém, e especialmente nos banhos. Os músicos tocavam em uma galeria superior, para o deleite dos que se divertiam embaixo. Já que os banhos estavam entre os lugares mais populares de encontros amorosos, esses músicos infelizes eram primeiro cegados e depois emasculados, para que não sofressem tentação. (DAVIS; MENUHIN, 1990, p. 64-65)

Foi justamente através da Espanha que a prática da castração no plano musical chegou a Europa. "Introduzidos pela civilização moçárabe por volta do século XII, certos eunucos, com sua voz espantosa, iriam pouco a pouco conquistando um lugar 
considerável na liturgia católica, para atingir o apogeu no século XVI.” (BARBIER, 1993, p. 7)

No caso dos castrati, como veremos posteriormente, a castração era feita, na maioria das vezes, contra a vontade do menino. Porém, existem relatos de povos nos quais adultos e jovens são castrados por vontade própria. É o caso de alguns povos da Índia, nos quais existe uma casta chamada hijra, freqüentemente traduzido como significando "nem homem nem mulher." (ROUGHGARDEN, 2004, p. 348). As hirja são do sexo masculino, mas, assumem-se como gênero feminino. Algumas nascem com pênis atrofiado, mas outras nascem do sexo masculino (machos), porém desejam viver como mulheres, chegando a se casar e com isso serem aceitas como "normais". "A cerimônia na qual as hirja são castradas se chama nirvana, e é feita por uma espécie de parteira dos povoados, as dai ma. A cerimônia custa caro, as hirja demoram algumas semanas para se recuperar, mas depois da cirurgia, existem 'provas de que a pessoa é uma verdadeira hirja, e não mais um impostor que se veste com roupas do sexo oposto'." (ROUGHGARDEN, 2004, p. 351)

A nirvana promove a feminização do corpo da hirja, que sem os testículos interrompe a fabricação de testosterona. "Hirjas consideram o resultado da operação a beleza, e não a mutilação.” (ROUGHGARDEN, 2004, p. 351). Nesse caso a intervenção corporal é voluntária, causando mudanças radicais tanto no corpo no papel social assumido pelos indivíduos que sofrem a castração, que passam a ser "aceitos" na sua sociedade, justamente o contrário do que ocorria com os castrati.

No Império Romano os eunucos eram considerados machos cujos genitais não "funcionavam". Apesar da castração ser considerada ilegal no império, "além" de suas fronteiras, muitos romanos sobreviveram como cirurgiões castradores, sendo que o Imperador Alexandre Severo (222-235 d.C) chamava os eunucos de "terceiro sexo". Um advogado romano desta época, Ulpian, enumerou três tipos de eunucos:

Eunucos por natureza eram aqueles cujos genitais não continuaram a se desenvolver na puberdade. Tal pessoa teria, ao nascer, genitais adequadas para ser classificada como macho. (No começo do Império Romano, crianças nascidas com genitais muito ambíguos para serem classificados inicialmente como machos ou fêmeas eram mortos). O segundo grupo era de eunucos castrados por procedimentos não cirúrgicos - amarrando o escroto para que os testículos se atrofiassem, ou esmagando os testículos, produzindo genitais que continuavam masculinos, mas não produziam esperma ou testosterona. Finalmente havia eunucos cujos genitais tinham realmente sido removidos cirurgicamente, levando a uma área genital não mais com aparência masculina. (ROUGHGARDEN, 2004, p. 355).

Depois da castração, se bem feita e antes da puberdade, os eunucos tinham seios, acumulavam mais gordura e preservavam a voz. Mas, alguns problemas de saúde acompanhavam o processo, como grande curvatura da espinha, osteoporose, pele amarelada, entre outros.

O comércio de eunucos em Roma era lucrativo e intenso, pois eles não podiam ser operados em Roma, mas eram extremamente apreciados como servos domésticos e guardiões de mulheres e crianças. Também eram intermediadores entre homens e mulheres e patrões e empregadas, pois sendo considerados indivíduos assexuados não ofereciam perigos de sedução a nenhum dos sexos. "O fato da maioria dos eunucos não terem família, facilitava seu acesso ao poder em cargos de comando no governo ou no exército, pois sem sucessores não havia ameaça para a sucessão imperial." (ROUGHGARDEN, 2004, p. 357).

Alguns eunucos romanos agiam e assumiam o papel do gênero feminino no 
relacionamento social, vestindo-se e agindo como mulheres. Outros procuravam relações homossexuais e alguns eram casados com mulheres, assumindo-se como gênero masculino.

Muitos dos eunucos desse período eram ministros poderosos e aconselhavam os imperadores ou membros da nobreza, mas alguns segmentos da sociedade aprovavam leis que baniam os eunucos de qualquer trabalho que estivesse relacionado à vida pública, confinando-os a trabalhos ligados à vida doméstica e as mulheres, como a limpeza dos banheiros femininos.

$\mathrm{Na}$ Bíblia também temos diversas referências aos eunucos, tanto no Velho como no Novo Testamento. Alguns trechos da Bíblia excluem os eunucos: "Aqueles cujos testículos são esmagados ou cujo membro masculino é cortado não devem entrar na assembléia do Senhor" (Deut. 23:1 RVS). Porém, o profeta Isaías torna claro que os eunucos podem ser aceitos na casa do senhor, desde que honrem o sábado judaico: Para tanto, o senhor diz: "Para os eunucos que guardam meus sábados, que escolhem as coisas que me agradam e abraçam rapidamente minha aliança, oferecerei minha casa e, dentro de minhas paredes, um nome melhor que filhos e filhas; darei a eles um nome eterno que não deverá ser removido" (Isa. 56:3-5 RSV).

Essas citações mostram a postura da Igreja, que sempre foi ambígua diante dos eunucos de qualquer época, porém, algumas interpretações das passagens que não excluíam os eunucos e falavam do celibato levaram muitos fiéis a se questionar se deveriam se tornar eunucos para serem aceitos por Deus: "um grupo de homens cristãos chamados valesianos praticavam auto-castração.” (ROUGHGARDEN, 2004, p. 363).

No cristianismo, a categoria dos eunucos também incluía mulheres masculinizadas, conhecidas como "santos travestidos". "Pela confiança que tenho em Cristo, não queria ser uma mulher. Agi principalmente como os homens, aceitando corajosamente a virgindade que há em Cristo.” (ROUGHGARDEN, 2004, p. 364). É interessante a visão de que como mulher a virgindade ou a devoção seriam menos valiosas do que como homens, afinal foi Eva quem seduziu Adão no paraíso!

No início do século $\mathrm{V}$, a idéia de celibato tomou força e se tornou o novo ideal masculino cristão. Com isso os eunucos foram sendo substituídos pelos monges masculinos e a castração passou a ser feita às escondidas.

A castração com intenção de manutenção vocal, tímida e oculta anteriormente, atingiu seu ápice no século XVII e XVIII. Ela era praticada em vários lugares por razões médicas, ou usando-se essas razões como subterfúgios. Muitos barbeiros, também médicos e dentistas, praticavam a orquiectomia em condições precárias.

Lá, como no hospital, a anestesia permanecia o primeiro ponto negativo: no melhor dos casos, podia consistir na absorção de beberragens contendo ópio a fim de neutralizar ao máximo as sensações da criança. O mais das vezes, contentavam-se em comprimir as carótidas para interromper momentaneamente a circulação: o menino se encontrava então num estado próximo do coma. Mergulhavam-no em seguida num banho de leite para amolecer as partes genitais, ou num banho de água gelada, que tinha também um ligeiro papel anestesiante e principalmente impedia que sangrasse demais. [...] Uma cifra, citada por certos médicos, situa a mortalidade entre 10 e $80 \%$, dependendo dos operadores.

A ação em si devia ser muito rápida: começava-se por uma incisão na virilha, pela qual o cirurgião puxava o cordão e os testículos. A ablação total era então efetuada com uma faca, enquanto os canais eram ligados. Essa operação diferia muito da dos eunucos de harém, de quem se retiravam todos os órgãos sexuais externos, geralmente depois da puberdade, o que já não lhes permitia conservar a voz de criança. (BARBIER, 1993, p. 10) 
O uso de eunucos nos haréns é conhecido de todos. Como a própria definição de castração nos mostra, alguns desses eunucos tinham apenas os testículos extirpados, outros apenas o pênis, outros ambos. Dessa forma acreditava-se que as mulheres estariam imaculadas e serviriam apenas aos seus senhores e reis. Já a castração por motivos musicais se limitava a retirada dos testículos para impedir a produção dos hormônios que "estragariam" a voz do menino. A voz resultante tinha a extensão vocal e a agilidade de um soprano aliada a força de um tenor ou baixo.

A castração começou a ser proibida no século XVIII e desapareceu por completo há cerca de cento e cinqüenta anos. Hoje ninguém sabe como soaria um castrato. Atualmente as personagens escritas para castrato, são substituídas por homens ou mulheres, conforme a montagem. Em 1922, morreu o último castrato natural "oficial" do qual se tem notícia, Alessandro Moreschi (1858-1922). É o único também do qual nos chegaram várias gravações, feitas entre 1902 e 1903.

\section{CONSTRUÇÃO CORPORAL DOS CASTRATI}

Resumidamente, a história dos castrati nos diz que, quando algum professor de música percebia que um menino tinha uma voz apropriada para o canto, convencia a sua família a fazer sua castração. Esta prática, segundo registros, já era feita pelos povos antigos, para suas músicas religiosas e de entretenimento. Importada pela Igreja Católica, que ao mesmo tempo em que os acolhia era contra a castração durante a Idade Média, o castrato foi amplamente aproveitado na ópera desde o seu início até o final do século XVIII. Se, por um lado, valorizava a vida musical e era considerado um "anjo cantor", por outro era visto por muitos como uma monstruosidade ou aberração.

Não obstante a crueldade de tal ato cirúrgico para nossa visão contemporânea, os castrati eram verdadeiros ídolos da ópera no período Barroco, muito mais famosos que os tenores de nossos dias. Esses cantores eram no período barroco "o que os roqueiros são para os nossos dias e os grandes malabaristas do piano foram para a Era Romântica." (COELHO, 2000, p. 185)

Foi a Itália o país que mais criou castratis e onde eles mais foram aclamados e amados pelo público, porém, a castração de muitos meninos era mal feita, apenas um dos testículos era retirado, por exemplo. Outros tinham três testículos (o que não evitava que sua voz engrossasse) e outros não acompanhavam a árdua jornada de estudos impostas aos meninos cantores. Para esses a castração não tinha trazido "bem" nenhum. Alguns se refugiavam nas igrejas virando monges e outros tiravam a própria vida. "Bastava o menor sinal de uma voz promissora para que mandassem castrar os seus filhos, e o resultado era que todas as grandes cidades abrigavam enorme quantidade daquelas criaturas patéticas ou sem voz nenhuma ou com voz insuficiente para compensá-los por perda tão grande." (COELHO, 2000, p. 193)

Bolonha tinha os mais hábeis cirurgiões, mas a castração praticada por médicos "competentes" era muito cara, o que levava muitos pais a castrarem seus filhos em casa ou com açougueiros e veterinários.

Se percebermos o corpo como uma manifestação cultural, isto é, como algo muito maior e mais completo do que um conjunto de órgãos ou partes, com um caráter único biológico, podemos imaginar como ficava a construção da imagem corporal desses meninos castrados. Tanto o corpo como suas representações e discursos são construídos 
em meio a uma sociedade, que dialoga constantemente com os indivíduos, desde o seu nascimento (ou até antes). Um menino de 8 ou 9 anos, no século XVII ou XVIII, tinha uma referência do que era ser "homem" e "mulher", assim como as crianças de nossos dias a tem, baseada nos discursos, imagens e representações do corpo. Apesar do conceito de beleza no barroco apresentar uma conotação diferente da atual, no qual faziam parte do imaginário popular seres mágicos e bizarros, os meninos castrados eram pessoas comuns, crianças que, com certeza, tinham uma referência do que era, também, na sua sociedade, ter um corpo "normal" ou "anormal":

O corpo é também o que dele se diz e aqui estou a afirmar que o corpo é construído, também, pela linguagem. Ou seja, a linguagem não apenas reflete o que existe. Ela própria cria o existente e, com relação ao corpo, a linguagem tem o poder de nomeá-lo, classificálo, definir-lhe normalidades e anormalidades, instituir, por exemplo, o que é considerado um corpo belo, jovem e saudável. Representações estas que não são universais nem mesmo fixas. (GOELLNER, 2003, p. 28)

Diante dessa referência de "normal" ou "belo", presente em todas as sociedades com suas particularidades, um corpo mutilado, de forma involuntária e dolorosa, com certeza, causava grande desconforto e confusão no que diz respeito à construção da identidade corporal desses meninos e, conseqüentemente, da sua atuação através de seu corpo na sociedade, tanto no que diz respeito à sua sexualidade como nas suas relações sociais em todos os âmbitos. Mesmo sabendo que esse corpo, valorizado como objeto e mercadoria, poderia trazer benefícios materiais futuros, passar da infância para a puberdade sem parte de seus órgãos genitais, causava nessas crianças uma série de incertezas em relação ao seu sexo/gênero, não facilmente resolvidas. Ser considerado mercadoria desde a infância até a velhice, esse era um destino certo para praticamente todos os castrati: "a maior parte das cortes italianas e européias davam grandes vantagens aos castrati e lhes garantiam rendas compatíveis. Certos príncipes caçavam encarniçadamente esses jovens cantores, depois trocavam-nos entre si." (BARBIER, 1993, p. 96).

O poder de alguns sobre o corpo de outros e o domínio dos mais poderosos e ricos sobre os mais fracos e submissos está presente constantemente na história humana. Os castrati sofriam essa dominação desde a infância, quando eram obrigados a se submeter a essa intervenção corporal material, a cirurgia ou a inúmeras intervenções corporais imateriais, quando eram educados severamente nos conservatórios e na juventude, quando vendiam sua voz, seu corpo, para quem pagasse mais.

No fim do século XVIII, os castrati foram atacados por todos os lados, tanto musical como ideologicamente. Filósofos de toda a Europa condenavam com veemência a castração, como podemos ver nas frases de Jean-Jacques Rousseau: "Façamos ouvir, se for possível, a voz do pudor e da humanidade que grita e se levanta contra esse costume infame; e que os príncipes, que o incentivam por sua demanda, enrubesçam pelo menos uma vez por prejudicarem de tantas maneiras a preservação da espécie humana." (ROSSEAU in BARBIER, 1993, p. 186)

\section{CONSIDERAÇÕES FINAIS}

Como se dá a formação social e sexual de um menino, castrado antes dos oito anos e que freqüentemente se vestia de anjo para cantar e velar o corpo de outras crianças, 
muitas vezes da sua idade? Que referencial masculino ou feminino tinha? Como era considerado pela sociedade que participava desses eventos e cerimônias? Esses meninos se consideravam homens, mulheres ou anjos?

“Partindo do princípio que 'macho' e 'fêmea' são categorias biológicas, enquanto 'homem' e 'mulher' são categorias sociais” (ROUGHGARDEN, 2000, p. 25) e, sem aprofundar, nesse momento, a discussão sobre o referencial também binário de gênero, como poderíamos "definir" quem eram essas crianças e qual papel assumiam? Biologicamente, não eram "machos". Socialmente, não eram homens. Eram, simplesmente, uma voz angelical...

Ao afirmarmos que esses meninos não estavam se formando ou assumindo um papel tipicamente masculino, é importante refletirmos sobre o que era ser um homem no período barroco. Villari, em seu livro "O Homem Barroco", classifica os seres humanos deste período nos seguintes grupos:o estadista, o soldado, o financeiro, o secretário, o rebelde, o pregador, o missionário, a religiosa, a bruxa, o cientista, o artista e o burguês. Como vemos nessa lista não só os castrati estão excluídos como os músicos de uma forma geral, os camponeses e os artesãos. Em nenhuma dessas classificações encontramos alguma referência sobre os castrati. Estranho, pois, como já dissemos, muitos castrati foram exageradamente famosos na sua época, seria como dizermos que ninguém conhece atualmente a Madona, Michael Jackson, Xuxa ou Ronaldinho. Os castrati representam, talvez, um papel tão incômodo para os estudiosos de todos os tempos, que pouquíssimas referências são feitas a esses homens/anjos, o que procuramos, de forma bastante elementar, resgatar com esse trabalho.

Depois de adultos os castrati transitavam entre o mundo dos homens e das mulheres, mas algumas vezes os rapazes castrados assumiam papéis que eram considerados imorais e mostravam a dificuldade de definição do seu sexo/gênero, mesmo em uma sociedade liberal como a barroca italiana: "[...] é verdade que em certos teatros, no lugar de mulheres, saltam (dançam) rapazinhos de bela aparência vestidos de mulher; mas é verdade também que suas atitudes aparecem muito mais licenciosas ou dissolutas que as das próprias mulheres." (BARBIER, 1993, p. 111).

Vê-se assim que, se analisarmos a condição das mulheres, historicamente construída, como um ser inferior, vulgar, tentador e imoral, os castrati, muitas vezes, foram colocados abaixo delas na pirâmide social, desde a sua formação.

Além do ciúme e da anatomia mutilada, muitas vezes os castrati tinham uma aparência afeminada, um corpo construído como feminino, tanto pela supressão dos hormônios masculinos quanto pela sua formação e atuação como mulher em diversos papéis, agregando à sua condição o estigma de homossexual:

No entanto, quer se queira ou não, é certo que as leis papais proibindo as mulheres nos espetáculos para salvaguardar a moral pública favorece a feminização de muitos homens, castrados ou não, tanto nas óperas quanto nas peças de teatro ou nos balés. Daí resultaram inúmeras ligações e paixonites entre atores e espectadores, entre protetores e protegidos. (BARBIER, 1993, p. 126)

Vivendo grandes tensões entre idolatria e exclusão, é perfeitamente compreensível que, a maioria dos castrati que atingia um grau satisfatório de riqueza e sucesso assumisse uma posição de arrogância e exercesse seu poder sobre todos aqueles que, muitas vezes veladamente, consideravam-nos aberrações. Crianças pobres, obrigadas a viver uma vida austera e rígida em conservatórios, quando conseguiam certa ascensão social experimentavam o prazer de dominar, assim como outrora haviam sido 
dominados;

Homens ou anjos, ídolos ou monstros, os castrati sobreviveram por quase três séculos, desafiando leis morais e racionais. Seu corpo fora mutilado, porém, era produtor da mercadoria mais valiosa do seu tempo: a voz aguda. Não podia procriar, porém, despertava desejo em homens e mulheres. Havia tido uma infância pobre e sofrida, porém, fora coberto de ouro e riquezas na juventude. Não era homem nem anjo... talvez, a união dos dois.

Atualmente não se conhece nenhum castrati, mesmo que se saiba que a castração masculina ocorre em casos médicos, nenhum menino submetido a esse processo cirúrgico se atreveria, hoje em dia, a se apresentar como cantor.

O que se sabe é que pouco se fala sobre os castrati. Seja por desconhecimento, por falta de documentação, por medo ou por razões morais e culturais, esses gigantes cantores raramente são mencionados.

\section{REFERÊNCIAS}

BARBIER, P. História dos castratti. Tradução de: Raquel Ramalhete. Rio de Janeiro: Nova Fronteira, 1993.

BASTOS, J. A. Educação tecnológica: conceitos, características e perspectivas. In: Revista Tecnologia e interação. Curitiba: CEFET-PR, 1988

BUTLER, Judith. Problemas de gênero: feminismo e subversão da identidade. Tradução de Renato Aguiar. Rio de janeiro: Civilização Brasileira, 2003.

CANCLINI, N. G. 1984. A Socialização da arte -Teoria e Prática na América Latina. São Paulo, Cultrix, 1984.

CARPEAUX, O . M. O livro de ouro da história da música - da idade média ao século XX. 6 . ed. Rio de Janeiro: Ediouro, 2004.

CARVALHO, M. G.; FEITOSA, S.; ARAÚJO, S.M.C. Tecnologia. (xerox) Curitiba, s/d.

COELHO, L.M. A ópera barroca italiana - História da ópera 1. São Paulo: Perspectiva, 2000.

DAVIS, C.; MENUHIN, Y. A música do homem. 2. ed. Tradução de: Auriphebo Berrance Simões. São Paulo: Martins Fontes, 1990.

DIGAETANI, J.L. Convite à ópera. Tradução de: Bruno Luiz Furlanetto. Rio de Janeiro: Jorge Zahar, 1988.

HUSSON, R. La voix chantée. Le chant. Paris: Gauthier-Villars Editeur, 1960.

LAQUER, T. Inventando o sexo - corpo e gênero dos gregos a Freud. Tradução de: Vera Whately. Rio de janeiro: Relume Dumará, 2001.

GOELLBER, S.V. A produção cultural do corpo. In: LOURO, G. L.; NECKEL, J.F.;

GOELLNER, S.V. (Organizadoras). Corpo gênero e sexualidade - um debate contemporâneo na educação. Petrópolis: Vozes, 2003.P. 28 - 52.

ROUGHGARDEN, J. Evolução do gênero e da sexualidade. Londrina, Planta, 2000.

SAFFIOTI, H.I.B.Gênero, patriarcado e violência. São Paulo: Perseu Abramo, 2004.

SCOTT, Joan. Gênero: Uma categoria útil de análise histórica. In EDUCAÇÃO E REALIDADE. 1995. p. 71-99.

SILVA, Sira da . Fisiologia da voz e técnica vocal. Curitiba, 1997. Datilografado.

STANLEY, J. Música clássica: Os grandes compositores e as suas obras primas. Tradução de: Maria José Bellino Machado. ?: Centralivros sob a chancela de Livros e livros, 1995.

WAUGH, A. Ópera: outra forma de ouvir. Tradução de: Kiril Ispolnov. Lisboa: Estampa, 2000. $<$ http://pt.wikipedia.org/wiki/Castração 